\title{
Dijital Haberleşme Çağında Yerel Basının Karşılaştığı Sorunlar
}

\author{
İbrahim Sena Arvas (Dr. Öğr. Üyesi) \\ Bolu Abant İzzet Baysal Üniversitesi Iletişim Fakültesi \\ ibrahimarvas@ibu.edu.tr \\ Orcid: 0000-0002-5558-6913
}

Başvuru Tarihi: 13.09.2018

Yayına Kabul Tarihi: 17.10.2018

Yayınlanma Tarihi: 21.01.2019

\section{Öz}

Düzenli olarak yayımlanan yerel gazetelerin en önemli gelir kaynaklarından birisi resmi ilanlardır. Basın İlan Kurumu'nun bünyesinde dağıtılan bu resmi ilanları alabilmenin ön koşulu gazetelerin basılı yani matbu olmasıdır. Türkiye'de her geçen gün, gerek evden gerekse mobil olarak internete bağlanma oranları artmaktadır. Türkiye İstatistik Kurumu verilerine göre, geniş bant İnternet erişim imkânına sahip hanelerin oranının 2017 yılı Nisan ayında \%78,3 olduğu tespit edilmiştir. Bu orana bakıldığında günümüzde dijital haberleșmenin diğer mecralarla kıyaslanamayacak kadar geliştiği görülmektedir. Gazetecilik alanında da kendini gösteren bu dijitalleşme süreci yerel gazetelerin internet ortamına taşınmasına imkân tanımıștır. Baskı ve dağıtım faaliyetlerinin yüksek maliyetler gerektirmesi yerel gazeteciler için internet ortamını son derece cazip kılmaktadır. Ancak resmi ilanlardan elde edilecek olan gelirden mahrum kalmamak amacıyla birçok yerel gazete basılı olarak yayım yapmaktan vazgeçememektedir. Yaygın basının tanınmış gazetelerinin kâğıt baskısından vazgeçerek dijitale yöneldiği günümüzde dar gelirli yerel basının resmi ilanlar nedeniyle matbaalara mahkûm kalması irdelenmesi gereken bir sorundur. Bununla birlikte genel ve yerel seçimlere aylar kala hem basılı olarak hem de internet ortamında ortaya çıkan ve siyasi ilanlardan pay almak amacıyla yayıncılık yapan naylon gazeteler de yerel basının mücadele etmesi gereken bir başka sorun olmaktadırlar. Gerek Basın İlan Kurumu, gerekse meslek örgütleri tarafından bu naylon gazetelerin yol açtığı haksız rekabete karşı önlemler alınması gerekmektedir. Bu çalışma dijitalleşen haberleşme ortamında yerel basının karşılaştığı söz konusu iki sorunu açıklamayı amaçlamaktadır.

Anahtar Kelimeler: Dijital Haberleşme, Yerel Basın, Resmi İlan, Naylon Gazeteler. 
Research Article

\title{
Issues that Local Press Encountered In the Digital Communications Age
}

\author{
İbrahim Sena Arvas (Asst. Prof. Dr.) \\ Bolu Abant İzzet Baysal University Faculty of Communication \\ ibrahimarvas@ibu.edu.tr \\ Orcid: 0000-0002-5558-6913
}

Date Received: 13.09 .2018

Date Accepted: 17.10 .2018

Date Published: 21.01.2019

\begin{abstract}
One of the most important income sources of regularly published local newspapers is official announcements. The prerequisite for receiving these official announcements distributed in the body of the Press Advertisement Authority is that the newspapers are pressed, ie printed. The rates of connecting to the internet both from the home and by the mobile are increasing day by day in Turkey. According to data of Turkey Statistical Institute, the proportion of households with broadband Internet access in April 2017 was determined to be 78.3\%. Looking at this ratio, it is seen that today digital communication has improved so much that it can not be compared with other counterparts. This digitalization process, which is also evident in the field of journalism, allows local newspapers to be moved to the internet environment. The high cost of printing and distribution activities makes the internet environment extremely attractive for local journalists. However, many local newspapers cannot give up publishing in print in order not to lose the income of the official announcements. Today, while well-known newspapers of mainstream press tend to give up paper printing and go to digital, it's an issue to be scrutinized that the local press of the low income is confined to the official announcements. Nonetheless, the fake newspapers, which appear both in print and on the internet environment near to general and local elections and publishes to get a share of political advertisements, are another problem that the local press must struggle with. It is necessary to take precautions against the unfair competition which these fake newspapers have caused by the Press Advertisement Authority and professional organizations. This notice intends to explain these two problems that the local press has encountered in the digitalized communication environment. The said explanations will also include suggestions for solutions to the problems and the precautions to be taken.
\end{abstract}

Keywords: Digital Communication, Local Press, Official Announcements, Fake Newspapers. 


\title{
Giriş
}

Gelișen internet teknolojisi sosyal yaşamın neredeyse tüm pratiklerinde köklü değişimler yaşanmasına neden olmaktadır. Gazetecilik de bu değişimden payına düşeni alan mesleklerin başında gelmektedir. İnternetle birlikte insanların gündemi takip etme, habere ulaşma ve okuma alışkanlıkları yeni boyutlar kazanmıştır. Gazetecilik pratikleri de kısa sürede bu gelişmelere ayak uydurmuştur. İnternet teknolojisinin yaygınlaşması ve beraberinde getirdiği dijitalleşme süreci geleneksel gazetecilik pratiklerine ait kodların güncellenmesini zorunlu hale getirmiştir. Geleneksel gazeteciliğe ait etik kodlar, yasal düzenlemeler, içerikler, biçim, dağıtım ve bu gibi birçok başlık dijital ortamda işlevsiz kalmaktadır. Bunlardan belki de en önemlisi; yerel basının başlıca maddi dayanağı konumunda olan resmi ilan ve reklamların dağıtımına ilişkin mevcuttaki gerekliliklerin dijital devrin gerçekleri karşısında işlevini yitirmeye başlamış olmasıdır.

\begin{abstract}
Küreselleşmeyle birlikte artan enformasyon akışı, McLuhan'ın deyimiyle; dünyayı küresel bir köy haline getirmiş, yerel medyaya olan ihtiyaç ve ona yüklenen anlam değişmeye başlamıştır. İletişim teknolojilerinin gelişme gösterdiği günümüz medya ortamında yerel nitelik taşıyan kimi olaylar, internet yoluyla tüm dünyaya ulaşmakta ve tüm insanlığın ortak sorunu niteliğini kazanmaktadır. İște bu aşamada, iletişimin küreselleștiği bir ortamda, Türkiye'deki yerel basının iletişim teknolojisinin nimetlerinden yararlanarak başat bir konuma gelmesi zorunluluk olarak karşımıza çıkmaktadır (Değirmencioğlu, 2007, 483).
\end{abstract}

Yaygın basın açısından basit görülebilecekbirçoksorun, yerel basın ölçeğinde oldukça büyük sıkıntılar ifade etmektedir. Genellikle yerel seçimlerin yaklaşmasıyla ortaya çıkan naylon diğer bir deyişle sahte gazeteler de bu sorunların başında gelmektedir. Özellikle dijital haberleşmeyle birlikte internet gazetesi yayınlamanın kolaylaşması naylon gazetelerin artmasına ve yerel basının maddi manevi zarar görmesine neden olmaktadır.

Bu çalıșmanın başlıca amacı dijitalleșen haberleșme sürecinde yerel basın özelinde gazetecilik uygulamaları açısından yapılması gereken güncellemelerin ve alınması gereken tedbirlerin belirlenmesidir. Dolayısıyla bu çalışma, mevcuttaki Türk Basın Kanunu'nun ve Resmi İlan politikalarının internette yer alan gazetecilik uygulamalarını ne derece kapsadığını incelemeyi amaçlamaktadır. Çalışmanın kapsamında söz konusu yasal düzenlemelerin güncel işlevlerinin yanı sıra Bolu yerel basını özelindeki dijitalleșme ve bu dijitalleșmenin gerekli kıldığı güncellemeler de yer almaktadır. Bu bağlamda gazetecilik uygulamalarına ilişkin güncel yasal düzenlemeler taranmış, Bolu Gazeteciler Cemiyeti Başkanı başta olmak üzere Bolu'da yayın ve yayım yapan gazetelerin sorumluları ile yüz yüze görüşmeler gerçekleștirilmiștir. $\mathrm{Bu}$ yöntemler ile toplanan veriler yerel basının dijitalleșen dünyanın gerçekleri karşısında yaşadığı sorunların tespit edilmesinde kullanılmıştır.

\section{Dijital Haberleşme Çağında Türkiye'de Gazetecilik Uygulamaları ve Yasal Bağlamda Karşılaşılan Sorunlar}

Geleneksel gazetecilik alanına yeni ve farklı boyutlar kazandıran internete Türkiye'de ilk giren gazete 2 Aralık 1995'de Zaman Gazetesi olmuştur. Yine Türk basınında internete giren ilk dergiler ise Temmuz 1995'de Aktüel, Ekim 1995'de ise Leman'dır. 1996'da internet üzerinden yayınlanmaya başlayan Xn adlı sanal gazete de (Özgen 2000, 60) internete özgü ilk gazetecilik uygulamalarından biri olarak kabul edilmektedir. 
27 Kasım 1996'da içeriğinin tamamını internete açan ilk gazete ise Milliyet Gazetesi'dir. 1997 yılının ilk günlerinde Hürriyet ve Sabah gazeteleri de Milliyet Gazetesi'ni takip etmişlerdir. Radikal Gazetesi 28 Mart 1998'de, Cumhuriyet Gazetesi ise 7 Mayıs 1998'de internete açılmıştır. Cumhuriyet Gazetesi 2000 yılının Nisan ayında internet üzerinden abonelik sistemini getirmiş ve abone olan okurlar kendilerine verilen şifreyle o günkü sayıya ulaşabilmişlerdir. Türkiye'de internet üzerinden bağımsız yayın yapan ilk site NetHaber'dir. Türkiye'nin o dönemde en büyük servis sağlayıcılarından biri olan Superonline'ın internet sitesine bağlı olarak kurulan NetHaber, Anadolu Ajansı ve Reuters'in haberlerini ziyaretçilerine ulaștırmıștır. Bu gelișme İnternet yayıncılığı için atılan önemli adımlardan biridir. İçeriği tamamen kendine özgü olan ve bağımsız yayıncılık yapan ilk internet haber sitesi, gazeteci Ahmet Tezcan tarafindan kurulan www.dorduncukuvvetmedya.com'dur. Televizyonda program olarak yayınlanan “Dördüncü Kuvvet Medya” bu olanağını kaybedince, internete taşınarak medya etiği konusunda duyarlı gazetecileri de aynı ortamda buluşturmuştur. Mayıs 1998'de İnternet üzerinden yayınlanmaya başlayan site, hiçbir gruba bağlı olmadan yayın yapan sitelerin de öncülüğünü yapmıștır (Milli Eğitim Bakanlı̆̆ı, 2011, 4).

İnternet, kendine özgü yapısından dolayı, sadece mevcut kitle iletişim araçlarından çıkan enformasyonun yayılmasına olanak veren bir araç olarak kalmamış, aynı zamanda enformasyonun yeniden üretildiği ve yeni biçimlerde sunulduğu bir ortam haline gelmiştir. İnternet gazeteciliği ile de iletişim alanına yeni kavramlar, yeni tanımlar, yeni boyutlar kazandırılmıştır (Çakır, 2007, 146). Temel işlevi birbiriyle bağlantılı iletişim ağları üzerinden iki yönlü bilgi akışını sağlamak olan internetin gazetecilik uygulamalarına ev sahipliği yapmaya başlaması çok kısa bir zaman almıştır. Bu süre zarfında klasik basılı gazeteler kâğıdın yanı sıra internet ortamında da varlık göstermeye başlamışlardır. Bunun yanı sıra sadece internet üzerinde varlık gösteren ve gazeteciliğin yeni uygulama alanları olarak tanımlanan internet gazeteleri ve haber portalları ortaya çıkmıștır.

Hayatın doğal akışının bir parçası haline gelen internet beraberinde birçok alanda yeni yasal düzenlemelerin ve güncellemelerin yapılmasını gerekli kılmıştır. İnternet teknolojisiyle birlikte, gazetecilik mesleğine ait etik kodlar ve mevcut yasal düzenlemeler de yetersiz kalmaya başlamıştır. İnternet, gazetecilik alanına yeni sorumluluklar getirmenin yanı sıra basın yoluyla işlenen suçların tanımını, etkisini ve kapsamını değiştirmekle kalmamıș, gazetecilerin sahip olduğu temel hakları da etkilemiştir. Birçok ülkede gazetecilik uygulamalarına ilişskin özel bir yasal düzen, yasalarla tanınan ve korunan özel haklar ile çeşitli sorumluluklar tanımlanmıştır. Örneğin, ülkemizde de 5187 sayılı Basın Kanunu ile yasal çerçeve çizilmiş, 195 sayılı Basın İlan Kurumu Teșkiline Dair Kanun ile resmi ilan ve reklamlardan yararlanma esasları düzenlenmiş ve 212 Sayılı Kanun ile Değişik 5953 Sayılı Kanun ile gazetecilerin hakları teminat altına alınmıştır. Ancak bu kanunların hiçbirisi internet teknolojisinin gazetecilik alanına getirdiği yenilikler çerçevesinde henüz güncellenmemiştirler. Dolayısıyla ülkemizde yasalar yasal metinler bağlamında gazeteci ve gazetecilik işi sadece kâğıt üzerindeki hali ile tanınmaktadır. Oysa gazetecilik açısından bakıldığında internet ortamı neredeyse kâğıdın egemenliğine son vermek üzeredir.

\subsection{Türk Basın Kanunu ve İnternet Haber Siteleri}

Türkiye'de internet üzerindeki gazetecilik uygulamaları 5651 sayılı İnternet Ortamında Yapılan Yayınların Düzenlenmesi ve Bu Yayınlar Yoluyla İşlenen Suçlarla Mücadele Edilmesi Hakkında Kanun kapsamında bir ceza ve sorumluluk düzenine tabidir. 5651 sayılı Kanun özellikleri bakımından ceza sorumluluklarını düzenleyen 
5187 sayılı Basın Kanunu'ndan farklı şekilde bir özel ceza kanunu değildir. 5187 sayılı Kanun'un sadece basılı gazeteleri kapsaması, internet ortamında yapılan gazetecilik uygulamalarının genel internet kanunu kapsamında değerlendirilmesine neden olmaktadır. İnternet üzerindeki gazetecilik uygulamalarını kapsayan her hangi bir yasal düzenin bulunmaması onun genel geçer yasal internet düzenine tabi olmasını zorunlu kılmaktadır. Bu durum gerek gazetecilik uygulamaları gerekse gazetecilik mesleği açısından ciddi sorunların ortaya çıkmasına neden olmaktadır.

5187 sayılı Basın Kanunu kapsamında İnternet haber sitelerinin yer almıyor olmaları ve süreli yayın olarak kabul edilmemeleri, burada yapılan habercilik uygulamalarının devlet tarafından gazetecilik faaliyetleri olarak tanınmadı anlamına gelmektedir. Böylelikle, internet haber siteleri ve buralarda görev yapan kişiler, Basın Kanunu'ndan doğan basın özgürlüğü hakkı, haber kaynağını açıklamaya ve bu konuda tanıklık yapmaya zorlanmama hakkı, süreli yayınların yayımı, dağıtımı ve satışının önlenmemesi, gibi haklardan mahrum kalmaktadırlar. Aynı zamanda bu yayınlar ve çalışanları yine aynı kanunda yer alan, zorunlu bilgilerin gösterilmesi, beyanname verilmesi, teslim yükümlülügüu, düzeltme ve cevapla ilgili yükümlülükler, yargıyı etkileme ve kimliğin açıklanması yasağı gibi yasal sorumlulukların da dışında bırakılmaktadırlar.

Gazetecilik alanında yaşanan bu çifte standart 2012 yılında kanun koyucu otoritenin de dikkatini çekmiş, ilgili kurumlar, sivil toplum ve meslek örgütleriyle fikir alışverişinde bulunarak 5187 sayılı Basın Kanunu'nu güncellemek için çalışmalara başlanmıştır. 2014 yılında Basın Kanunu Güncelleme Tasarısı hazırlanmış, Türkiye Büyük Millet Meclisi Başkanlığı'na, esas komisyon olan Adalet Komisyonu'na ve tali komisyon olan Avrupa Birliği Uyum Komisyonu'na gönderilmiştir. Her iki Komisyon'un da raporlarını hazırlayarak teslim ettiği Tasarı henüz yürürlüğe girmemiştir.

\subsection{Türkiye'nin Resmi İlan Politikası ve İnternet Haber Siteleri}

Resmi ilan; devlet eliyle hazırlanan kanunlar, tüzükler ve yönetmeliklerce gazetelerde yayımlanması zorunlu tutulan ilanları tanımlayan ibaredir. Resmi ilanlar, kamu kurum ve kuruluşları ile sermayesinin yarısından fazlası kamu kurumlarına ait olan kuruluşların reklam mahiyeti dışında kalan ilanlarıdır. Bunun yanı sıra özel şirketlerin, vakıfların, sendikaların ve kooperatiflerin kanunen yayımlatması zorunlu olan ilanlar da resmi ilan statüsünde değerlendirilirler.

Ülkemizde yazılı basın olarak nitelendirilen gazete ve dergilerin bağımsız yayın politikasıyla hayatlarını sürdürebilmelerinin yolu, her ülkede olduğu gibi, yüksek satış ile yayımlanan ilan gelirlerinden geçmektedir. Özellikle sürekli ekonomik sıkıntılarla baş etmek durumunda olan yerel basın kuruluşları için bu ilan gelirleri deyim yerinde ise temel ihtiyaçlardır. Bu bağlamda, ülkemizdeki resmi ilan yayımı tarihçesine de kısaca değinmek gerekmektedir.

Türk basın tarihinde gazetelerde ilk ilan yayınına, 1840 yılında Ceride-i Havadis'in "ilanat" başlı̆̆ını taşıyan sütunlarında rastlanmaktadır. Zamanla diğer gazeteler de vefata iliş̧kin bilgiler taşıyan ve ilgi gören ilanlar, yayımlamışlardır. Daha sonra satılık gayrimenkul, yeni çıkan kitap, araba ve at ilanları gazetelerin sütunlarında kendine yer bulmuştur. Bu dönemde gazeteler, hükümetten gelen talepler doğrultusunda resmi ilan (resmi duyuru) olarak nitelendirilebilecek yazıları da okuyucularına ulaştırmıştır. Söz konusu dönemde ilan yayınlatmak, ücreti dolayısıyla o kadar da kolay olamamıştır. Gazetelerin nüshası 3-3,5 kuruşa satılırken, bir ilanın satır fiyatı 10 kuruşa kadar 
çıkmaktadır. Ülkemizde resmi ilanların dağıtılmasında aracılık görevine ilișkin ilk hukuki düzenlemeye 1864 tarihli Matbuat Nizamnamesi'nde yer verilmiștir. Resmi ilanların ücretsiz yayınlamasını zorunlu kılan bu düzenleme, her ne kadar 1877 yılında kanunda yapılan değişiklikte ortadan kaldırılmış gibi gözükse de uygulama, 1909'da çıkan Matbuat Kanunu ile sona ermiş ve resmi ilanlar ücretleri karşılı̆̆ında yayınlanmaya başlamıștır. $\mathrm{Bu}$ dönemde hükümetin resmi ilanlarının gazetelere dağıtılması görevini, 1862 yılında kurulan Matbuat Müdürlüğü (Bugünkü Basın Yayın Enformasyon Genel Müdürlüğü) üstlenmiștir. Matbuat Müdürlüğü'nün herhangi bir kurala bağlı kalmaksızın istediği gazetede resmi ilanı yayınlatma uygulaması, 1925 yılında aracılık işini üstelenen Mütekaidin-i Askeriye Anonim Şirketi tarafından da sürdürülmüștür (Basın İlan Kurumu, 2018).

$\mathrm{Bu}$ dönemde kamu yararı kaygısıyla üç imtiyaz verilmiştir. Birincisi 1925'de Mütekaidin-i Askeriye Anonim Şirketi'ne verilmiștir. İkincisi 1931 yılında Türk Maarif Cemiyeti ve üçüncüsü de 1943 yılında Türk Basın Birliği ve ortaklarına verilmiştir. Bu imtiyazlar ya hiç kullanılamamış ya da çok sınırlı bir dönemde kullanılabilmiştir. Yazılı bir imtiyaza sahip olmasa da 1931 öncesinde küçük ilâncıları organize ederek resmi ilânların gazetelere tek kanaldan dağıtımını sağlayan bir başka kurum da Anadolu Ajansı'dır. Bu bağlamda resmi ilânların gazetelerde yayınlatılmasına aracılık işi için Mütekaidin-i Askeriye A.Ş. adına bir hükümet kararı alınsa da uygulanamadığı varsayılan 1923-1930 arası, resmi ilânların gazetelere dağıtımı serbest piyasa koşullarında yapılmıştır. Bundan dolayı söz konusu yıllar "serbest" dönem olarak anılmaktadır.1931 yılında imtiyaz verilen Türk Maarif Cemiyeti ilk yıllarda belli bir para karşılığında haklarını Resmi İlânlar Türk Limited Şirketi'ne devretmiştir (Üstün, 2010, 17).

Resmi ilanlar 1931 yılına kadar ilgili kurumun seçtiği gazetelerde yayınlatılmıștır. Serbest dönem olarak adlandırılan bu yıllarda resmi ilanların dağıtımı özel ilanlar gibi gerçekleşmiştir. 1931 yılından sonra İstanbul, Ankara ve İzmir'de yayınlatılacak resmi ilanların aracılık hakkı Muharip Cemiyeti'ne verilmiş ve Cemiyet'in kurduğu şirket 1943 yılına kadar özellikle ihale ilanlarının dağıtımını yapmıştır. 1943 yılında resmi ilan aracılık hakkı Basın Birliği'ne verilmiştir. Dönemin hükümeti 27 Kasım 1957'de bir kararname çıkararak özel ve resmi bütün ilanların Resmi İlan Şirketi aracılığıyla yayınlatılması uygulamasına girmiştir. Ayrıca ihale yasası değiştirilerek ilanların yayınlanacağı gazeteleri doğrudan hükümetin seçmesi uygulamasına gidilmiştir (Şeker, 2005, 108).

1958 yılının ilk günlerinde dönemin hükümeti tarafından yayınlanan bir kararname ile ilan ve reklamların tek elden dağıtımı kabul edilmiştir. Gazeteler tarafından tepkiyle karşılanan bu karar sonucu bazı gazetelerde önemli ilan kısıtlamaları yapılmış, bir kısım gazetelerin ise resmi ilan gelirleri artmıştır (Topuz, 2003, 202).

1960’a kadar süren bu dönemde hükümet ile gazeteler, resmi ilan dağıtımları ve yayınları konusunda karşı karşıya gelmiştir. Basın özgürlüğü tartışmalarının yaşandığı bu dönem, 2 Ocak 1961'de 195 sayılı Basın İlan Kurumu'nun kuruluşuna ilişkin kanunun kabul edilerek, 9 Ocak 1961'de resmi gazetede yayımlanmasıyla sona ermiștir (Basın İlan Kurumu, 2018).

\subsection{1. İnternet Haber Sitelerinin Basın İlan Kurumu’ndaki Yeri}

Resmi ilan dağıtımındaki adaletsizliklere ve aksaklıklara son verilmesi amacıyla kurulan Basın İlan Kurumu'nun temel fonksiyonu gazete ve dergilerin, mevzuat hükümlerine göre resmi ilan yayınlama şartlarını taşıyıp taşımadığını tespit ederek, bu şartları taşıyan gazete ve dergilere, şubeler aracılığıyla resmi ilan/ 
reklam dağıtımını sağlamaktır. 195 sayılı Kanun ile kurulan Basın İlan Kurumu'nun dağıttığı söz konusu ilan ve reklamlardan faydalanılabilmesi için yerine getirilmesi gereken bazı görev ve sorumluluklar bulunmaktadır. Bu bağlamda Kurum, gazeteleri, yayınlandığı şehir, türü, yayım süresi, sayfa yüzölçümü, günlük fiili satış ortalaması ve içerik yönünden incelemeye tabi tutmaktadır. İncelemelerde gazete veya derginin, mevzuat hükümlerini ihlal edip etmediğine bakılmaktadır. Basın İlan Kurumu her ayın sonunda resmi ilan verilebilecek gazete ve dergilerin listesi ile üçer aylık devreler halinde resmi ilan tarife ücretlerini, Kurum internet sitesi üzerinden duyurmaktadır.

Söz konusu şartlara bakıldığında ilanı talep eden gazetenin basılı yanı matbu olmasının resmi ilan almanın temel şartı olduğu açıkça anlaşılmaktadır. Özellikle yerel basının başlıca gelir kalemlerinden olan resmi ilanların varlığ çok sesli demokratik düzenin basın yoluyla desteklenmesinde önemli bir rol oynamaktadır. Basın İlan Kurumu bir yandan resmi ilanların adaletli ve kesintisiz bir şekilde gazetelere ulaştırılmasını diğer yandan bu ilanlara ait ücretlendirme ile bir nevi basının devlet eliyle gelir elde etmesini sağlamaktadır.

Ülkelerde demokratik düzenin varlığı yerel medyanın güçlü olmasıyla mümkündür. Devlet idarecileri demokratik düzeni sürdürebilmek için yerel basını maddi olarak güçlendirmek zorundadırlar (Demirkent, 1998, 33). Resmi ilan ve reklamların varlığı da yerel basının güçlendirilmesi için devletin elindeki yegâne araçtır.

Mevcut haliyle Basın İlan Kurumu'nun bünyesinde dağıtılan bu resmi ilanları alabilmenin ön koşulu gazetelerin basılı yani matbu olmasıdır. Baskı ve dağıtım faaliyetlerinin yüksek maliyetler gerektirmesi yerel gazeteciler için internet ortamını son derece cazip kılmaktadır. Ancak resmi ilanlardan elde edilecek olan gelirden olmamak amacıyla birçok yerel gazete basılı olarak yayım yapmaktan vazgeçememektedir.

Basın İlan Kurumu'nun Resmi İlan ve Reklamlar ile Bunları Yayınlayacak Süreli Yayınlar Yönetmeliği'nde internet haber siteleri ve resmi ilanlar konusunda 05 Ekim 2016 tarihinde bir güncelleme yapılmıştır. Buna göre, resmi ilanların dağıtım ve yayınlanma ilkesini içeren madde 29'a şu ibare eklenmiștir; "Resmî ilânlar yayınlandığı gazetenin imtiyaz sahibine ait internet sitesinde eş zamanlı olarak yayınlanır." Söz konusu maddeye son olarak 20 Aralık 2017 tarihinde de; "birden fazla gazetenin imtiyaz sahibinin aynı olması durumunda her bir gazetenin ayrı internet haber sitesi olması gerekir." ifadesi eklenmiștir.

Bu değişiklikler ile Basın İlan Kurumu'nun internet haber sitelerinin önemine dikkat etmeye başladığı anlaşılmıştır. Ancak yukarıdaki ifadelerden de anlaşılacağı gibi adı geçen internet haber sitelerinin resmi ilan alma hakkına sahip olan basılı gazetelerin internet sürümleridir. Sadece bir internet haber sitesinin tek başına resmi ilanlardan faydalanabilmesi Basın İlan Kurumu yönetmelikleri uyarınca mümkün değildir.

Yaygın basın organlarının, basılı gazetelerinin yayımını sonlandırarak sadece internet ortamında yayın yapmaya başladığı günümüzde, resmi ilan politikasının halen basılı yani matbu yayınları zorunlu kabul etmesi güncellenmeye muhtaç bir durumdur. Bu durum kanun koyucu otoritenin de dikkatini çekmiş ve 2014 yllında internet haber sitelerinin yaşadığı mağduriyetleri gidermek amacıyla bir kanun tasarısı hazırlanmıştır. 
Başbakanlığa arzı Bakanlar Kurulu'nca 10 Şubat 2014 tarihinde kararlaştırılan söz konusu Kanun Tasarısı'nın Türkiye Büyük Millet Meclisi Başkanlığı'na sunulması ancak 12 Mart 2014 tarihinde mümkün olabilmiştir. Tasarının genel gerekçesinde internet üzerinde gazetecilik mesleğini yürütenlerin haklarının teminat altına alınmasıyla ilgili olarak; "internet haber siteleri, gazetelerin sunmuş olduğu kâğıt üzerindeki haberleri sanal ortamda okuyucuların hizmetine sunmakta, buna mukabil basılı gazetelere ve gazetecilere tanınmış olan haklardan istifade edememektedirler." ifadesi kullanılmıştır.

Basın Kanunu Güncelleme Tasarısı olarak da anılan bu metnin internet haber sitelerine kazandırdığı en önemli hak; bu sitelerin resmi ilan alabilmelerine imkân veren düzenlemedir. 195 sayılı Basın İlan Kurumu Teşkiline Dair Kanun'a eklenen bir madde ile internet haber sitelerinde de resmi ilan ve reklam yayınlatılmasının önü açılmıştır. Bu yayına ilişkin esas ve usuller ise Basın Yayın Enformasyon Genel Müdürlügü, Bilgi Teknolojileri ve İletişim Kurumu ile Basın İlan Kurumu Genel Müdürlüğü'nün hazırlayacağı yönetmeliğe bırakılmıştır. Bilindiği gibi düzenli olarak yayımlanan yerel gazetelerin en önemli gelir kaynaklarından birisini resmi ilanlar oluşturmaktadır.

Adalet komisyonu tarafından da çeşitli muhalefet şerhleri konulan Tasarı, yine aynı Komisyon tarafından, "Adalet Komisyonu'nun Kabul Ettiği Metin” başlığı ile revize edilerek Türkiye Büyük Millet Meclisi Başkanlığı'na geri gönderilmiștir. 2014 yılından bu yana söz konusu tasarıyla ilgili herhangi bir gelişme yaşanmamıştır.

\subsubsection{Bolu Basını Özelinde İnternet Haber Siteleri ve Resmi İlan Politikası}

Basın İlan Kurumu ilan ve reklam dağıtımında yukarıda söz edilen özellikler dışında çeşitli içerik denetimleri de gerçekleştirmektedir. İlan verilen gazetelerin günlük asgari fiili satışlarının yanı sıra gazetelerdeki haberlerin güncel ve özgün olup olmadığını, baskı kalitelerini de denetlemektedir. Kurum bu denetlemeler ile sadece resmi ilan pastasından pay almak için yayımlanan gazetelerin varlığını engellemeyi hedeflemektedir.

$\mathrm{Bu}$ hedef doğrultusunda Basın İlan Kurumu'nun yerel basının niteliğini arttırmak amacıyla küçük ölçekli yerel gazeteleri birleşmeye teşvik ettiği, böylece yerel basında bir kalite artışı sağlama politikasını benimsediği bilinmektedir. Kurumun bu politikası yönerge, yönetmelik, hedefler ve amaçların yer aldığı metinlerde yer almamakta ancak son dönemde yerel basında yaşanan gazete birleşmelerinden açıkça anlaşılmaktadır. Söz konusu birleşmeler bazı basın mensupları tarafından çok sesliliğe zarar verebilecek bir dayatma olarak algılansa da, bu politikayı benimseyerek birleşme yoluna giden gazetelerin sayısı bir hayli fazladır.

Örneğin sadece 2013 yılında Mersin ilinde gazete sayısı 16'dan 8'e, Afyon'da 21'den 13'e, Erzurum'da 16'dan 4'e ve Sivas'ta 15'den 3'e düşmüştür.

Basın İlan Kurumu'nun birleștirme politikası Bolu yerel basınında da etkili olmuştur. Kurumun Bolu Şube Müdürlügü 2014 yılının Aralık ayında açılmıştır. Kurumun söz konusu birleşme politikası bir buçuk yıl gibi kısa bir sürede Bolu basınında da etkisini göstermiştir. 2016 Eylül'ünde Bolu'da yayımlanan 7 günlük gazete birleșerek 3 gazete haline dönüşmüştür. 
Bu doğrultuda Bolu Gündem Gazetesi, Bolu Olay Gazetesi ile birleşerek Bolu Olay Gündem Gazetesi adını almıștır. Bolu Ekspres Gazetesi, Bolu Takip Gazetesi ile birleșerek Bolu Takip ismini sürdürmüștür. Diğer taraftan Bolu'da yayım yapan Köroğlu Gazetesi de, Memleketim Bolu gazetesinin ilan haklarını satın alarak Köroğlu ismi ile yayım yapmaya devam etmiştir. Son olarak söz konusu 6 yerel gazete birleşmeler sonucu 3 gazete haline dönüşmüştür. Bu 3 gazete de kendi aralarında anlaşarak Bolu Detay Gazetesi'nin ilan haklarını satın almış ve birleşme hamlesi 7 gazeteden 3 gazeteye şeklinde sonuçlanmıştır. Söz konusu gazetelerin sadece Basın İlan Kurumu'ndan ilan alma hakkına sahip gazeteler olduğunun altının çizilmesi gerekmektedir.

Adı geçen 3 gazete Bolu il merkezinde günlük yayımlanmaktadır. Bolu'da bunlara ek olarak resmi ilan alan ve Bolu il sınırları içerisinde yayım yapan ancak bir ilçe ile anılan Gerede Medya Takip isimli bir gazete de bulunmaktadır. Bu gazete ile Bolu'da Basın İlan Kurumu'ndan ilan alan gazete sayısı 4'tür.

Sözü edilen gazetelerin Basın İlan Kurumu'na bildirdikleri baskı sayılarının toplamı 5 bini geçmemektedir. Toplam baskı sayıları 5 bin civarında 4 yerel gazete de abonelik sistemi ile dağıtıma öncelik vermektedir. Bu gazetelerin yanı sıra Bolu'da internet haber sitesi olarak düzenli şekilde güncellenen ve profesyonel olarak yayın yapan dijital yayın organları da bulunmaktadır. İmtiyaz sahibi, yazı işleri müdürü ve muhabirleri bulunan bu internet haber sitelerinin sayısı azımsanamayacak kadar fazladır. Bolu ilinde dijital olarak yerel medya kapsamında değerlendirilebilecek belli başlı internet haber siteleri şu şekilde sıralanabilir;

- bolununsesi.com

- bizbolulular.com

- ozgurbolu.com

- tvbolu.com

- boluobjektif.com

- bolugazetesi.com.tr

- boludabolu.com

- yenisesimiz.com

- boluyanki.com

- bolugundem.com

- boluekspres.com

- medya14.net

Yukarıda sıralanan yerel internet haber sitelerinin toplam günlük tekil ziyaretçi sayısı 50 bin civarlarındadır. Yüz yüze ve telefonla görüşme tekniği kullanılarak yapılan bu hesaplama sonucunda günümüzde dijital medyanın basılı gazetelere oranla çok daha fazla takip edildiği görülmektedir. Bu veriden hareketle gazetecilik mesleği birincil geçim kaynağı olan ve bu mesleği profesyonel olarak icra eden insanlar dijital ortam söz konusu olduğunda basılı bir yayın organına sahip olmadıkları için resmi ilanlardan pay alamamaktadırlar. Buna ek olarak söz konusu haber siteleri 5187 sayılı Basın Kanunu tarafından tanınmamaktadırlar. Aynı zamanda gazetecilere ciddi haklar tanıyan 212 ile değişik 5953 sayılı Basın Mesleğinde Çalışanlarla Çalıştıranlar Arasındaki Münasebetlerin Tanzimi Hakkındaki Kanun'da internet üzerindeki gazetecilik uygulamalarını kapsamına almamaktadır. 
Sonuç olarak basına sağlanan devlet desteğinin, siyasal çıkar ve baskılardan uzak bir biçimde, kişisel tercihler yerine, nesnel ölçütlerlegerçekleştirilmesiöngörülerek, fikir ve içtihat farkı aranmaksızın resmi ilanların basın organlarında yayımlanmasında aracı olmak amacıyla 1961 yılında çıkarılan, 195 sayılı Basın İlan Kurumu Teşkiline Dair Kanun artık işlevini yitirmiștir. Yasada, resmi ilanların dağıtımında göz önünde tutulan; içerik, sayfa sayısı ve ölçüsü, kadro, fiili satış, en az yayın hayatı süresi, ölçütleri, artık günün koşullarına uydurulmalıdır (Girgin, 2007, 259).

\section{Dijital Haberleşme Çağında Naylon Gazetelerin Yerel Basına Etkisi}

Naylon kelimesi; sahte, düzme anlamına gelmektedir (Larousse, 1992, 8564). Naylon kelimesi gazetecilik alanında da sıkça kullanılan bir tabirdir. Sözlük tanımından da anlaşılacağı gibi, naylon gazete için; düzme ve sahte anlamları çıkarılabilmektedir. Bir başka deyişle naylon gazeteler; gazete görünümünde reklam ve ilan içeren broşürlerdir. Söz konusu gazeteler için meslek erbapları tarafından "balon gazete" ve "vur kaç gazetesi" benzetmeleri de yapılmaktadır.

Naylon gazetelerin yayımlanış amacı genellikle, yerel ya da genel seçimler öncesi ortaya çıkarak siyasi içerikli ilan ve reklamlardan elde edilecek gelirden pay almaktır. Basın meslek örgütleri tarafından da varlığı tespit edilen naylon gazetelere sıklıkla dikkat çekilmektedir. Örneğin 25-27 Mart 2011 tarihinde Ordu ilinde Türkiye Gazeteciler Cemiyeti'nin ev sahipliğinde düzenlenen Türkiye Gazeteciler Federasyonu'nun 33. Başkanlar Konseyi Toplantısı'nda, söz konusu gazetelerin varlığına dikkat çekilmiştir. Gazeteciler Federasyonu üyesi 42 meslek örgütü başkanı veya temsilcisinin katıldığı toplantıda naylon gazeteler konusu kamuoyuyla paylaşılacak kararlar içerisine dâhil edilmiştir. Naylon gazetelere dikkat çeken söz konusu karar şu şekildedir (Türkiye Gazeteciler Federasyonu, 2011);

Her seçim öncesinde özellikle Anadolu'da, "Naylon gazete ve gazeteciler" türemekte ve yaptıkları yayınlarla meslek etik ve kurallarını hiçe saymaktadırlar. Tüm siyasi partilerimizi ve adaylarımızı bu konuda uyarıyoruz. Seçim dönemlerinde sadece etik olmayan yollardan para kazanmak amacıyla ortaya çıkan; şantaj ve tehdit amaçlı bu tip yayınlara ödün verilmemesini ve etik değerlere saygılı, sürekli, ilkeli ve istikrarlı yayın yapan gazeteler ve gazetecilerimizle bunların aynı kefeye konulmamasını arzu ediyoruz.

Genellikle seçim zamanlarına birkaç ay kala ortaya çıkan söz konusu gazeteler 5187 numaralı Basın Kanunu'nun 7. Maddesi'nde yer alan, kaydedilmek üzere yönetim yerinin bulunduğu ilgili Cumhuriyet Başsavcılığı'na beyanname verilmesi, hükmüne uymazlar. Zira bu gazeteleri yayımlayan kişilerin amacı yayımladıkları gazetenin süreli yayın özelliğine sahip olmasından çok seçim dönemi sona ermeden elde edilecek maddi geliri maksimum düzeye çıkartmaktır. Tanımından da anlaşılacağı gibi naylon gazetelerin kamu hizmeti ve halka haber vermek gibi endişeleri yoktur. İçeriklerinin büyük bir bölümünü siyasi reklamlar oluştururken, yayımladıkları haberlerin de büyük bir bölümü, parti veya aday propagandası niteliği taşımaktadır. Söz konusu haberler de reklam ve ilanlarda olduğu gibi maddi karşılıklar doğrultusunda hazırlanmaktadır. Bu gazetelerde yer alan haberlerin hemen hemen hiç birisi haber yazma kurallarına uymamaktadır.

Öyle ki yerel seçim dönemi yaklaştığında bir ilde aniden daha önce hiç yayımlanmamış onlarca naylon gazete ortaya çıkabilmektedir. Yerel seçim dönemi 
sona erdiğinde yayın hayatına devam eden gazeteler, seçim dönemini hakları olan geliri sağlayamadan geride bırakırlar (Arvas, 2007, 362-363).

Bilindiği gibi Türkiye'de gazete yayımlamak başta Türkiye Cumhuriyeti'nin taraf olduğu Avrupa İnsan Hakları Sözleşmesi'nin 10. Maddesi olmak üzere Türkiye Cumhuriyeti Anayasası'nın, Haberleşme Özgürlüğü başlıklı 22. Maddesi, Düşünceyi Açıklama ve Yayma Özgürlüğü başlıklı 26. Maddesi ve Basın Özgürlüğü Başlıklı 28. Maddesi uyarınca serbesttir. Bu serbestlik ayrıca 5187 sayılı Basın Kanunu'nun, Basın Özgürlüğü başlıklı 3. Maddesi ile de yinelenmiştir.

Türkiye'de gazete yayımlamak için yukarıda da değinildiği gibi 5187 numaralı Basın Kanunu'nun 7. Maddesi'nde yer alan, kaydedilmek üzere yönetim yerinin bulunduğu ilgili Cumhuriyet Başsavcılığı'na beyanname verilmesi yeterlidir. Gazete yayımlamanın bu denli kolay olduğu ülkede naylon gazete yayımlayanların çoğunluğu bu beyanı yapmaktan bile acizdirler. Ancak artan baskı, kağıt ve dağıtım masrafları naylon gazeteler için dijital ortam daha cazip kılmaktadır.

Dijital ortamda internet haber sitesi yapma işinin, beyanname muafiyeti ve devlet tarafından gazetecilik kapsamında değerlendirilmemesi, ortamı naylon gazete yayınlayan firsatçılar için oldukça cazip kılmaktadır. Seçimler öncesi sosyal medya platformlarında yayın yapacakları ilin vatandaşlarını bir araya toplayacak sayfalar kurarak ișe bașlayan naylon gazeteciler, yeterince takipçi kazandıktan sonra internet haber sitelerini oluşturarak bu platformlardan tanıtımını yapmaktadırlar. İnternet haber sitesi oluşturmak için kullanımı son derece basit ve ücretsiz şablonlar kullanan bu kişiler kısa sürede haber sitelerini oluştururlar. Bu haber sitelerinin genellikle künyeleri bulunmamaktadır. Künye bulunanların künyelerinde yer alan imtiyaz sahibi ve sorumlu müdür adları ise ekseriyetle düzmece olmaktadır. Seçimlerde aday adayı ya da aday olan siyasilerden ilin gerçek gazetelerinin talep ettiği reklam ve ilan ücretlerinin çoğu zaman yarısından daha azını talep ederek haksız kazanç sağlayan bu naylon yapılar, yerel basına ciddi zararlar vermektedirler.

Yerel basın kuruluşları için yerel ve genel seçimlerde toplanacak ilan ve reklam gelirleri oldukça önemlidir. Birçok yerel basın mensubu seçimleri deyim yerinde ise dört gözle beklemektedir. Naylon gazetelerin ortaya çıkmasını engelleyecek herhangi bir yasal düzenlemenin yapılmasının ifade özgürlüğü bağlamında imkânsız olması gerçek yerel basını çaresiz durumda bırakmaktadır.

\subsection{Naylon Gazetelere Karşı Alınabilecek Önlemler}

Herhangi bir izin sistemine bağlı olmayan, dileyen herkesin düşünceyi ifade özgürlüğü kapsamında gazete yayımlayabildiği Türkiye'de naylon gazetelerin yayımlanmasını engellemek gerek uluslararası anlaşmalara gerekse ülkedeki anayasal ve yasal düzene aykırıdır.

Türkiye Gazeteciler Cemiyeti de "Yerel medya Eğitim Seminerleri" adıyla düzenlediği, eğitim seminerlerinde naylon gazetelerle mücadeleye sıklıkla yer vermektedir. Gazeteciler Cemiyeti'nin de konuya ilişkin çözüm önerilerinden birisi şöyledir (2004);

Yerel medyada gazetecilik mesleğinin kişisel çıkarlar için kullanılması veya para ve diğer çıkarlar karşılığında naylon gazeteler çıkarılmasının önlenmesi için meslek ilkeleri ve etik kuralların hassasiyetle ve kararlı biçimde uygulanması gazetecilerin görevi ve sorumluluğudur. Naylon gazete veya benzeri yayın çıkarmanın veya benzeri amaçlarla 
görsel ve işitsel yayın yapmanın engellenmesi için yasal sınırlandırmaların; ifade özgürlüğ̈̈nü ortadan kaldırmadan, demokratik toplum düzeni ölçütleriyle çelişmeden ve demokrasiyi zedelemeden gözden geçirilmesinde yarar vardır.

Basılı gazete yayımlamak herkese tanınan anayasal bir hak iken, söz konusu eylemi dijital olarak ifa etmeyi engellemek imkânsızdır. Dezenformasyona oldukça açık olan internet ortamı naylon gazetelerin inandırıcı etkileriyle birlikte deyim yerinde ise tam bir yerel basın katliamına ev sahipliği yapmaktadır. Dijital ortamda gerçekleștirilen habercilik uygulamalarının devlet tarafından gazetecilik kapsamında değerlendirilmiyor olması da bu tarz haberciliğin cüretkâr bir biçimde hızla yaygınlaşmasına neden olmaktadır.

Yasal yaptırım bağlamında naylon gazetelerin gerek basılı gerekse dijital sürümlerine yaptırım uygulamanın mümkün olmadığı günümüzde söz konusu yapılarla mücadele etmenin yegâne yolu, "teşhir yoluyla utandırma" yaptırımının aktif olarak kullanılmasıdır. Bu yaptırım genellikle özdenetim kuruluşları tarafından başvurulan bir cezalandırma sistemidir. Bu yaptırım genellikle basın konseylerinin kullandığı bir yaptırımdır (Arvas, 2014, 65);

Gönüllülük esasına dayanarak kurulan ve işleyen konseylerin, yukarıda sözü edilen, uyarı, kınama ve şikâyeti yersiz bulma cezaları, söz konusu cezalardan herhangi birinin uygun görüldüğü basın organını ya da basın çalışanını, çarptırıldığı cezanın çeşitli şekillerde kamuoyuna duyurulması ile teşhir yoluyla utandırma amacını taşır. Gazetecilik gibi saygınlı̆̆ın ön planda olduğu bir meslekte bu teşhir durumu cezayı alan kurum ya da kişi için itibar zedeleyici olmaktadır.

Türkiye'de 1988 yılında kurulmuş olan Türk Basın Konseyi de yukarıda yer alan yaptırımları uygulamaktadır. Ancak Türk Basın Konseyi'nin yaptırımlarının kamuoyu ve Türk basını üzerinde çok da etkinliği olduğu söylenemez. Kaldı ki Konsey söz konusu yaptırımları kendi bünyesinde belirlenen Basın Meslek İlkeleri çerçevesinde uygulamaktadır. Söz konusu ilkeler içerisinde naylon gazetelerle ilgili bir maddenin bulunmayıșı da söz konusu teșhir yoluyla utandırma yaptırımının Türk Basın Konseyi tarafından uygulanamayacağını göstermektedir. Konseyin yerel basının sorunlarından ziyade yaygın basınla ilgilendiğini söylemek mümkündür.

Yerel basın konusunda en fazla çalışmayı yapan meslek kuruluşu Türkiye Gazeteciler Cemiyeti'dir denilebilir. Cemiyet uzun yıllar gerçekleştirilen Yerel Basın Eğitim Seminerleri dizisinin düzenleyicisidir. Bu seminerlere en üst yönetimi düzeyinde katılım da gösteren cemiyet naylon gazeteler sorununa sıklıkla değinmiş ve çareler aramıştır. Türkiye Gazeteciler Cemiyeti'nin yanı sıra Türkiye'nin her ilinde bir Gazeteciler Cemiyeti örgütlenmesi bulunmaktadır.

Bu gerçeklerden hareketle, başta Türkiye Gazeteciler Cemiyeti olmak üzere her ilin ilgili Gazeteciler Cemiyeti örgütlenmesiyle birlikte, Basın İlan Kurumu Müdürlükleri, gerçek anlamda yayıncılı yapan yerel gazetelerin de destekleriyle, uyarı ve kınamalar ile naylon gazeteleri gerek dijital platformlarda gerekse basılı süreli yayınlarda teşhir edebilirler. Tespit edilen naylon gazeteden yayını (dijital veya basılı) durdurması ya da kısa sürede gerçek bir gazete gibi imtiyaz sahibi, sorumlu müdürden oluşan bir künye belirlemesi, Basın Kanunu'ndan doğan sorumluluklarını yerine getirmesi konusunda bir uyarı verilmesi mümkündür. Basın Konseyi ve Gazeteciler Cemiyeti'nin oluşturacağı bir değerlendirme kurulu uyarı yaptırımının gereğinin yapılmaması durumunda ilgili gazeteyi tüm imkânları ile gerek dijital ortamda gerekse süreli yayınlarda kınayarak ifşa edebilirler. 


\section{Sonuç}

Resmi ilanlar, devlet tarafından yerel basına oldukça ciddi maddi kaynaklar sağlayan duyurulardır. Birçok yerel basın kuruluşu söz konusu ilanlardan faydalanabilmek için ellerindeki tüm imkânları seferber etmektedir. Resmi ilanların adil dağıtımından sorumlu olan Basın İlan Kurumu da gerekli değerlendirmelerden sonra bu ilanları ilgili gazetelere dağıtır ve ödemeleri gerçekleștirir. Basın İlan Kurumu'nun ilan dağıtmayla ilgili esasları 195 sayılı Basın İlan Kurumu Teşkiline Dair Kanun ve yönetmeliklerle belirlenmiștir. Kurum özellikle 2010 yılından sonra yerel gazeteleri birleștirme politikası benimsemiştir. $\mathrm{Bu}$ politikası doğrultusunda nicelikten ziyade nitelik hedefleyen Kurum, birleşmeyi kabul eden yerel basın kuruluşlarını desteklemeyi sürdürmüștür. Bu sayede yerel basında kalitenin artıp artmadı̆̆ı ayrı bir tartışma konusudur. Asıl tartışılması gereken bu çalışmanın da temel konularından birisi olan; bir gazetenin resmi ilan alabilmesi için basılı yani matbu olma zorunluluğudur.

Bolu özelinde resmi ilanla ilgili rakamlar da devletin resmi ilan politikasının artık işlevsiz olduğunu ve milli kaynakların etkili kullanılması politikasıyla uyuşmadığını kanıtlamaktadır. Bolu'da resmi ilan alma hakkına sahip 4 gazetenin toplam baskı sayıları 5 bini geçmemektedir. Bu gazetelerin birçoğu abonelik sistemi ile dağıtılmaktadır. Söz konusu gazetelerde yer alan resmi ilan ne derece okunduğu ölçülmesi zor bir istatistiktir. Son dönemde yapılan değişikliklerle Basın İlan Kurumu yayımlattığı resmi ilanları ilgili gazetelerin internet sürümlerinde de yayımlanmasını şart koşmaktadır. Bolu özelinde en köklü yayın organı olan bu 4 gazetenin internet sayfaları sayesinde resmi ilanlar az da olsa amacına ulaşmaktadır. Söz konusu bu gazeteler resmi ilanlardan faydalanabilmek için mutlaka basılı bir gazeteyi Basın İlan Kurumu'na ulaştırmak zorundadır. Oysa bahsi geçen gazetelerin internet sitelerinin tekil ziyaretçi sayısı baskı sayılarından kat ve kat fazladır. Bolu özelinde internet haber sitelerinin tekil günlük ziyaretçi sayısı 50 bine yakındır. Hal böyle iken ve yaygın basının önemli markalarından olan Radikal ve Haber Türk gibi gazetelerin basılı sürümlerini yayımdan kaldırdığı da göz önünde bulundurulursa, yerel basının kâğıda ve matbaalara muhtaç bir biçimde resmi ilan almaya çalışması çağın gerçekliğiyle örtüşmemektedir. Basılı sürüm yayımlamak gazetelerin kendi isteklerine ve imkânlarına bırakılmalıdır.

Gazetelerin baskı sayıları belli olsa da bu rakamların ne derece gerçek olduğu tartışmalıdır. Bunun yanı sıra dağıtımın hangi titizlikle yapıldığı ve ilgili gazetenin kaç kişi tarafından okunduğu ölçülmesi zor bir istatistiktir. Buna karşı, internet siteleri kolaylıkla kendilerine ait günlük tekil ziyaretçi sayısı gibi ölçülebilir veriler sağlamaktadırlar. Resmi ilanlarda dijital ortamın kapsama dâhil edilmesinin yerel basına istihdam konusunda da bir hareket alanı açması da muhtemeldir.

Söz konusu sorunun çözümü nispeten 2014 yılında tamamlanan ve çalışmada yer alan Basın Kanunu Güncelleme Tasarısı'nda yer almıștır. Tasarı Basın Kanunu'nun yanı sıra 195 sayılı Kanunu da güncelleyerek internet haber sitelerinin devlet tarafından tanınmasını aynı zamanda 212 Sayılı Kanun ile Değişik 5953 Sayılı Kanun ile dijital ortamda mesleğini yapan gazetecilerin haklarının teminat altına alınmasını da düzenlemiştir. Söz konusu tasarının 25 Haziran 2018 seçimleri sonrasında değişen yeni yönetim sistemine uygun olarak güncellenmesi ve vakit kaybetmeden yasalaşması resmi ilan sorununa çare olacaktır. 
Dijitalleşmeyle birlikte hızla artan naylon gazeteler de yerel basının mücadele etmesi gereken bir başka sorundur. Söz konusu sorunun devlet eliyle çözülmesi evrensel manada ifade özgürlügü hakkını zedeleyeceği için imkânsızdır. Bu sorunun çözümü için de bir an önce basınla ilgili meslek örgütleri ile Basın İlan Kurumu bir araya gelerek yeni ve etkili çözüm yolları bulmak zorundadırlar.

\section{Kaynakça}

Arvas, İbrahim S. (2007). Naylon Gazeteler ve Besleme Basının Yerel Basına Etkileri. Türkiye'de Yerel Basın, İstanbul Üniversitesi Yayınları, 357-364.

Arvas, İbrahim S. (2014). Türk Basınında Etik ve Özdenetim, İstanbul: Beta Yayınevi.

Basın İlan Kurumu (2018). Resmi İlan Tarihçesi. Erişim: 27 Temmuz 2018, http:// www.bik.gov.tr/ kurumsal/resmi-ilan-tarihcesi/

Büyük Larousse Sözlük ve Ansiklopedisi (1992). Milliyet Yayınları, 16.

Demirkent, N. (1998). Yerel Gazeteciliğe Genel Bakış. Yerel Gazetecilik, Televizyonculuk ve Radyoculukta Meslek İçi Eğitim, Yerel Basın Eğitim Seminerleri Dizisi, 6, 33-50.

Değirmencioğlu, G. (2007). Yeni İletişim Teknolojilerinin Yerel Basına Sunduğu Olanaklar ve Kocaeli Yerel Gazetelerinin İnternet Sayfaları Üzerine Bir Değerlendirme. Türkiye'de Yerel Basın, İstanbul Üniversitesi Yayınları, 475-494.

Girgin, A. (2007). Türkiye'de Yerel Basın ve Resmi İlan. Türkiye'de Yerel Basın, İstanbul Üniversitesi Yayınları, 243-260.

Milli Eğitim Bakanlığı (2011). Gazetecilik, Internet Haberciliği, 321GM0022, MEB Program Modülü.

Özgen, M. (2000). İnternet ve Türkiye'de İnternet Gazeteciliği. İstanbul Üniversitesi İletişim Fakültesi Hakemli Dergisi, 10, 57-64.

Şeker, M. (2005). Yerel Gazeteler ve Resmi İlan, Selçuk Üniversitesi İletişim Fakültesi Akademik Dergisi, C.4, 1, 101-115.

Topuz, H. (2003). II. Mahmut'tan Holdinglere Türk Basın Tarihi, İstanbul: Remzi Kitabevi.

Türkiye Gazeteciler Cemiyeti (2004). Yerel Medya Eğitim Seminerleri Değerlendirme Toplantısı Sonuç Bildirgesi. İstanbul: Gazeteciler Cemiyeti Yayınları.

Türkiye Gazeteciler Federasyonu (2011). 33. Başkanlar Konseyi Toplantı Kararları. Erişim: 17 Temmuz 2018, http://www.tgf.com.tr/baskanlar-konseyi/bk-33toplantisi-25-27-mart-2011-ordu-h291.html

Üstün, H. (2010). Türkiye'de Devletin Yazılı Basına İlan ve Reklam Dağıtım Politikaları ve Basın İlan Kurumu Örneği. Doktora Tezi, İstanbul Üniversitesi. 